\title{
Infix Allomorphy in Ida'an-Begak
}

\author{
Nelleke Goudswaard \\ Vrije Universiteit Amsterdam
}

\section{Introduction}

Ida'an-Begak is a Western Malayo-Polynesian language spoken by approximately 6,000 people on the east coast of Sabah, Malaysia, Borneo and belongs to the Sabahan subgroup of the North Borneo subgroup (Blust 1998). Ida'an-Begak has three dialects, Ida'an, spoken in the villages of Segama to the west of Lahad Datu, Ida' an Sungai spoken in the Kinabatangan and Sandakan districts, and Begak spoken in Ulu Tungku, to the east of Lahad Datu (Banker 1984). ${ }^{1}$ Moody (1993) deals with Ida' an; this paper concentrates on the Begak dialect. In this paper I will present new data gathered in the field and provide an analysis of the allomorphy. The study is based on spontaneous data as well as examples elicited from my language informants.

Several languages of this group show infixation/prefixation allomorphy, where the vowel of the infix allomorph coalesces with the stem vowel (Blust 1997's 'ablaut'). Ida'an-Begak shows a rather complex instantiation of this phenomenon. In this paper I will present new data gathered in the field and provide an analysis of this allomorphy.

The Ida'an-Begak Past Tense (P) is marked by $n i-,-i$ - or -on-, depending on the shape of the stem, while the Dependent (D) is marked by $m$-, $-u$ - or -am-, depending on the shape of the stem. ${ }^{2}$ The distribution of these infixes is as in Table 1. Stems that start with a consonant followed by schwa or $/ \mathrm{a} /$ are infixed with $-i-(\mathrm{P})$ and $-u$ - (D), resulting in vowel coalescence. Stems that start with a consonant followed by a high vowel are infixed with -on- (P) and - $2 m$ - (D); vowel-initial stems are always prefixed with $n i$ - (P) and $m$ - (D). Stems starting with a liquid followed by a high vowel are prefixed with $n$ ə- $(\mathrm{P})$ and $m$-(D). The result of the affixation is ideally a consonant-initial bisyllabic form, which is the optimal prosodic word of the language.

\begin{tabular}{|l|l|l|l|l|l|l|}
\hline $\begin{array}{l}\text { Stem } \\
\text { Starts } \\
\text { With }\end{array}$ & stem & Gloss & P. affix & Past Tense & D. affix & Dependent \\
\hline $\mathrm{V}$ & abput & 'bite' & $n i-$ & nebput & $m-$ & mabput \\
\hline $\mathrm{Ca} / \mathrm{C} ə$ & səgkow & 'call' & $-i-$ & sigkow & $-u-$ & sugkow \\
\hline $\mathrm{Ci}$ & timbak & 'shoot' & - -ən- & tənimbak & - əm- & təmimbak \\
\hline $\mathrm{Cu}$ & tunu & 'set on fire' & $-i-$ & tinu & $-ə m-$ & təmunu \\
\hline $\mathrm{Li}$ & ligow & 'deceive' & $n ə-$ & noligow & mə- & moligow \\
\hline
\end{tabular}

Table 1: Distribution of the suppletive allomorphs

The morphemes of the Past Tense and the Dependent derived historically from proto-Austronesian ${ }^{*} \mathrm{IN}$ and $* \mathrm{UM}$ respectively (Blust 1997). Contrary to Ussishkin (2000)'s analysis of the same phenomenon in the related language Mukah Melanau, I will claim that the synchronic allomorphs in Ida'an-Begak are no longer derived from one underlying form. Synchronically, 
they must be analysed as suppletive affixes that still bear resemblance to *IN and *UM but never surface as such. The claim of this paper is that allomorphy in Ida'an-Begak is suppletive and that the choice of allomorphs is governed by constraint ranking. The phonology decides which allomorph fits best for which stem.

In the next section I will describe which constraints are needed to obtain this optimal consonant-initial bisyllabic form. In section 3, the interaction between the various constraints is analyzed. In section 4, arguments are presented in favour of an analysis with suppletive allomorphs, and section 5 offers some conclusions.

\section{Description of the data and possible constraints}

The attachment of the Past Tense and Dependent affixes always results in consonant-initial words. Therefore ONSET must be rather highly ranked in Begak. ONSET is active in various parts of the phonology. The language uses for example glide insertion and vowel coalescence to avoid vowel hiatus. Sometimes, glottal stops are inserted if a word starts with a vowel. Nevertheless, certain words (nouns and stative verbs) may start with a vowel; in that case ONSET is overruled by other constraints.

(1) ONSET: "A syllable must have an onset" (Prince \& Smolensky 1993:99)

The second constraint that we need to adopt is that a word must be a foot, i.e. a word is maximally and minimally two syllables long. This constraint explains why Begak strives towards bisyllabic words.

(2) PRWD=FT: "a word is a foot / maximally two syllables long"

This constraint is a slight modification of PRWD=BIN: a Prosodic Word must be binary (Prince \&Smolensky 1993: 55). ${ }^{3}$

The third constraint that we need to adopt says that only the last two syllables of a word can have a full vowel. Not all words are bisyllabic, but if they are longer, for example after a bisyllabic stem has been prefixed or infixed, the syllables before the penultimate one can only contain an empty vowel. All prefixes have the shape $\mathrm{C}-, \mathrm{C} ə(\mathrm{C})-$ or $\mathrm{C} ə \mathrm{C} 2-$ and the three noncoalescing infixes have the shape -əC-, thereby filling non-footed syllables with schwa ${ }^{4}$ : 
(3)

\begin{tabular}{|c|c|}
\hline$g \partial^{-}$ & Actor Voice \\
\hline bəg- & Actor Voice \\
\hline məng- & Actor Voice \\
\hline$k ә$ & $\begin{array}{l}\text { Actor Voice- } \\
\text { Stative }\end{array}$ \\
\hline məngə- & $\begin{array}{l}\text { Actor Voice } \\
\text { causative }\end{array}$ \\
\hline po- & $\begin{array}{l}\text { Dependent } \\
\text { causative }\end{array}$ \\
\hline nə- & $\begin{array}{l}\text { Past Tense } \\
\text { causative }\end{array}$ \\
\hline to- & Intensive \\
\hline mokə- & Petitive \\
\hline$n g-$ & Nominalization \\
\hline
\end{tabular}

$\begin{array}{ll}\begin{array}{l}\text { gə-lindut } \\ \text { bəg-arab }\end{array} & \begin{array}{l}\text { 'sun' } \\ \text { məng-inum }\end{array} \\ \begin{array}{l}\text { kəlapas } \\ \text { 'drink' } \\ \text { məngə-lawas }\end{array} & \text { 'massed by' } \\ \text { pə-buay } & \text { 'make clean' } \\ \text { nə-lewas } & \text { 'made clean' } \\ \text { tə-buat } & \text { 'very long' } \\ \text { məkə-ledung } & \text { 'ask for help to go down' } \\ \text { səng-əgkot } & \text { 'manner of work' }\end{array}$

Infixes in Begak have only schwa as their vowel:

$\begin{array}{llll}\text {-or- } & \text { Reciprocal } & s \text {-or-agga' } & \text { 'fight with each other' } \\ \text {-ən- } & \text { Past Tense } & t \text {-ən-iru' } & \text { 'taught' } \\ \text {-əm- } & \text { Dependent } & t \text {-əm-iru' } & \text { 'teach' }\end{array}$

Just like some other North Bornean languages, Begak does not have any productive suffixes, but even historically suffixed words have schwa in the prepenultimate syllable:

$\begin{array}{llll}\text { turug } & \text { 'sleep' } & \text { torug-an } & \text { 'bed' } \\ \text { tapis } & \text { 'strain' } & \text { topis-an } & \text { 'strainer' } \\ ? & & \text { kə-topus-an } & \text { 'last' } \\ ? & & \text { kəlogbung-an } & \text { 'ridgepole' }\end{array}$

The Stative prefix $a$ - is the only exception; it forms a kind of appendix and appears to the left of all other prefixation.

$\begin{array}{llll}\text { (6) ligot } & \text { 'late' } & \text { a-ligot } & \text { 'rather late' } \\ \text { tot } & \text { 'stuck' } & a-p-\vartheta-t o t & \text { 'accidentally stuck' } \\ \text { luan } & \text { 'go out' } & a-k ə-\text { luan } & \text { 'accidentally go out' } \\ \text { inum } & \text { 'drink' } & a-k ə-p \text {-inum } & \text { 'accidentally drink' }\end{array}$

Blust (1997:21) formulates the vowel distribution of North Bornean languages as Prepenultimate Neutralization. This can be turned into the following constraint:

(7) Prepenultimate NeUtralization (PPN): "Every unfooted syllable is reduced to schwa."

PPN is actually a weaker form of the constraint PRWD $=F T$ mentioned above and can therefore perhaps better be split up in two separate constraints: $\mathrm{PRWD}_{\mathrm{R}}=\mathrm{FT}$ and a form of Positional Faithfulness (Beckman 1997, Alderete 
1995) or Licensing (Steriade 1994a,b, Zoll 1998). Positional Faithfulness deal with faithfulness constraints of elements in "strong" positions while Licencing deals with the markedness of elements in "weak" positions. Although PPN can be split up, I will use the constraint PPN to deal with unstressed syllables, for ease of exposition.

The fourth observation on Table 1 is that vowel coalescence is often used to avoid vowel hiatus and to keep words bisyllabic. Malay loan words containing a vowel hiatus or a sequence of a glide and a vowel are adapted by means of vowel coalescence, as in (9). This means in OT terms that UNIFORMITY must be ranked low in Begak.

(8) UNIFORMITY: "no element of $\mathrm{S}_{2}$ has multiple correspondents in $\mathrm{S}_{1}$ " (McCarthy \& Prince 1995)

(9)

$\begin{array}{llll}\text { Malay } & \text { gloss } & \text { Begak } & \text { gloss } \\ \text { wayang } & \text { 'movie' } & \text { oyang } & \text { 'movie' } \\ \text { wayar } & \text { 'wire' } & \text { oyar } & \text { 'wire' } \\ \text { tuala } & \text { 'towel' } & \text { tola' } & \text { 'towel' } \\ \text { pəlihara } & \text { 'look after' } & \text { (pə)lera' } & \text { 'look after' } \\ \text { jarum }[\text { djarum] } & \text { 'needle' } & \text { derum } & \text { 'needle' } \\ \text { ajaib }[\text { adjaib] } & \text { 'miraculous' } & \text { deip } & \text { 'astonished' } \\ \text { janji } \text { [djandji] } & \text { 'promise' } & \text { dendi } & \text { 'vow' }\end{array}$

Begak has only four underlying vowels: $/ \mathrm{a} /, / \mathrm{i} /, \mathrm{u} /$, and $/ \mathrm{o} /$ in final syllables and $/ \mathrm{a} /, / \mathrm{i} /, / \mathrm{u} /$ and schwa in penultimate syllables.

$(10)$

\begin{tabular}{|l|l|l|l|}
\hline & Front -Round & & Round Back \\
\hline High & i & & $\mathrm{u}$ \\
\hline -High -Low & $\mathrm{e}$ & $\mathrm{e}$ & $\mathrm{o}$ \\
\hline Low & & $\mathrm{a}$ & \\
\hline
\end{tabular}

The two derived vowels /e/ and /o/ can only occur as a result of vowel coalescence in the penultimate syllable. These vowels are actually two vowels realized in one segment and can be represented as in (11). The vowel schwa is always overwritten by /i/ and / $/$ / after vowel coalescence, because schwa has no features to start with.

\begin{tabular}{|c|c|c|c|}
\hline V & V & $=$ & $\mathrm{V}$ \\
\hline 1 & [high front -round] & & [high front -round] \\
\hline ( & 1 & & 1 \\
\hline $\mid a /$ & /i/ & & $/ \mathrm{i} /$ \\
\hline V & $+\quad \mathrm{V}$ & $=$ & V \\
\hline & [high back round] & & [high back round] \\
\hline$d$ & 1 & & 1 \\
\hline /a/ & $/ \mathrm{u} /$ & & $/ \mathrm{u} /$ \\
\hline
\end{tabular}




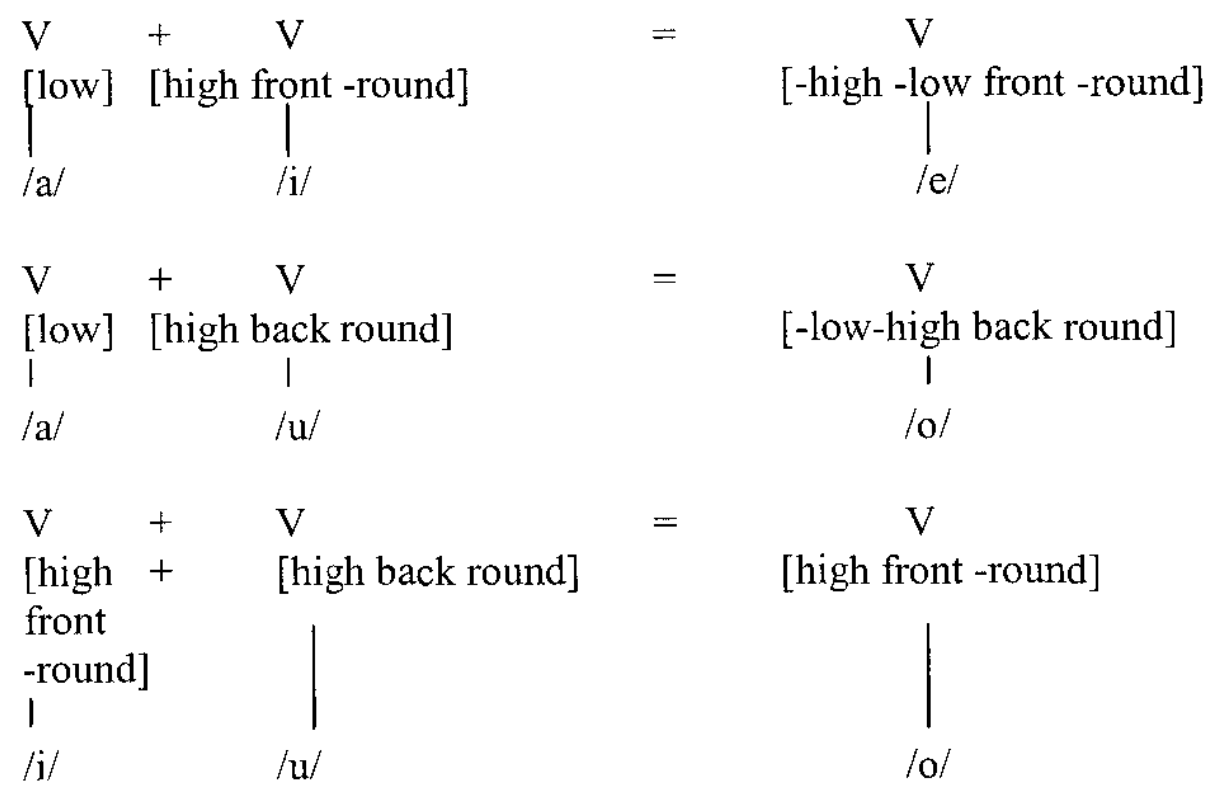

Other combinations of vowels are not involved in coalescence because in the case of affixation, an other allomorph is chosen. If the stem vowel $/ \mathrm{u} /$ is infixed with $-i$ - it is overwritten by it, for example / $t-i$-unu/ 'burn' becomes tinu, but the opposite does not occur: stems with a penultimate /i/ cannot be infixed with $-u$-, for example $* / \mathrm{t}$-u-jru'/ but $t$-əm-iru' 'teach'. This is an idiosyncracy that I cannot explain.

The last constraint that needs to be adopted for the analysis of the Past Tense and Dependent allomorphy forbids complex onsets: *COMPLONSET (Prince and Smolensky 1993). Begak native words lack complex onsets and complex onset in loan words are adapted, as is illustrated in (12).

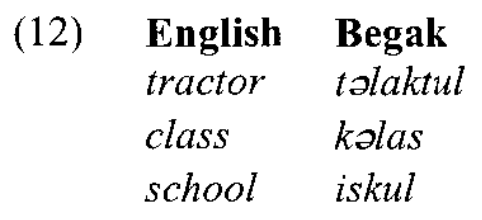

\section{Analysis}

We can now adopt the following hierarchy of the constraints:

\section{(13) ONSET, PPN, *COMPLONSET $>>$ PRWD $=$ FT $>>$ UNIFORMITY}

As for the choice between infixation and prefixation, it is possible to adopt an alignment constraint ALIGN (affix, L) (Prince\&Smolensky 1993, McCarthy 2002) for Begak, because the language has no productive suffixes. All its affixes are prefixes, or infixes that are affixed after the first consonant of the stem. Nevertheless, I will not discuss any constraints that refers to the place of affixes, because Alignment constraints are so low on the hierarchy that they do not influence the choice of the allomorph. ${ }^{5}$ 


\subsection{Consonant-initial verbs}

Table (2) shows the Past Tense of the verbs sagkow 'call', dalud 'wait' and sukot 'ask'. The prefixed candidates *nisəgkow, *nidalud and *nisukot have a full vowel in an unfooted syllable, and are therefore ruled out. The candidates infixed with $-2 n$ - are too long and violate $\mathrm{PRWD}=\mathrm{FT}$. The last candidates are the optimal candidates despite the fact that they violate UNIFORMITY because of their vowel coalescence: these candidates are bisyllabic and consonant-initial.

\begin{tabular}{|l|l|l|l|l|l|}
\hline Affix & $\begin{array}{l}\text { səgkow 'call'/ dalud 'wait'/ } \\
\text { sukot 'ask' }\end{array}$ & ONSET & PPN & PRWD=FT & UNIFORMITY \\
\hline$n i-$ & nisəgkow / nidalud / nisukot & $* !$ & $*$ & \\
\hline- - n- & sənəgkow/ dənalud / sənukot & & $* !$ & \\
\hline$-i-$ & sigkow / delud / sikot & & & & $*$ \\
\hline
\end{tabular}

Table 2 Past Tense of verbs starting with $\mathrm{C}$, $\mathrm{Ca}$ or $\mathrm{Cu}$

The Dependent allomorphy in Table (3) can be explained in almost the same way: the prefixed candidates *msogkow and *mdalud fatally violate *COMPlOnset; the infixed candidates *saməgkow and *domalud are too long and the candidates sugkow and dolud win despite vowel coalescence.

\begin{tabular}{|l|l|l|l|l|}
\hline Affix & $\begin{array}{l}\text { səgkow 'call' } \\
\text { / dalud 'wait' }\end{array}$ & *COMPLONSET & PRWD=FT & UNIFORMITY \\
\hline $\mathrm{m}-$ & msəgkow/mdalud & $* !$ & & \\
\hline- -əm- & səməgkow /dəmalud & & $* !$ & \\
\hline$-\mathrm{u}-$ & sugkow /dolud & & & $*$ \\
\hline
\end{tabular}

Table 3 Dependent of verbs starting with $\mathrm{C} 2$ or $\mathrm{Ca}$

Verbs starting with a consonant followed by the vowel /i/ cannot be infixed with $/ \mathrm{i} /$ in the Past Tense because vowel coalescence cannot take place. Two identical adjacent vowels are forbidden, therefore *tiiru' is out. An antihomophony constraint is needed for the Past Tense of verbs starting with $\mathrm{Ci}$ and the Dependent of verbs starting with $\mathrm{Cu}^{6}$

(14) MORPHDIS: "A segment cannot belong to more than one morpheme." (McCarthy \& Prince 1995). ${ }^{7}$

The form *tiru' is bisyllabic and consonant-initial but nevertheless this form is out because it violates the constraint MorphDis. The optimal candidate is then toniru', even if it is trisyllabic: 


\begin{tabular}{|l|l|l|l|l|l|l|}
\hline $\begin{array}{l}\text { Past Tense } \\
\text { affix }\end{array}$ & $\begin{array}{l}\text { Stem } \\
\text { tiru' } \\
\text { 'teach' }\end{array}$ & ONSET & PPN & MORPHDIS & PRWD=FT & UNIFORMITY \\
\hline ni- & nitiru' & & $* !$ & & $*$ & \\
\hline -on- & təniru' & & & & $*$ & \\
\hline$-\mathrm{i}-$ & tiiru' & $* !$ & $*$ & & $*$ & \\
\hline$-\mathrm{i}_{-}$ & tiru' & & & $* !$ & & $*$ \\
\hline
\end{tabular}

Table 4 Past Tense of verbs starting with $\mathrm{Ci}$

The selection of the Dependent allomorph of consonant-initial verbs with a high penultimate vowel, as in Table 5 can be explained in the same way: prefixation with $m$ - results in an illicit, clustered onset while infixation with $-u$ in combination with vowel coalescence is impossible here. Therefore the optimal candidate is infixed with $-2 m$-, even though it renders the form trisyllabic.

\begin{tabular}{|l|l|l|l|l|l|l|l|}
\hline $\begin{array}{l}\text { Dependent } \\
\text { affix }\end{array}$ & $\begin{array}{l}\text { Stem } \\
\text { sukot } \\
\text { 'ask' }\end{array}$ & ONSET & PPN & $\begin{array}{l}\text { COMPL } \\
\text { ONSET }\end{array}$ & $\begin{array}{l}\text { MORPH } \\
\text { DIS }\end{array}$ & $\begin{array}{l}\text { PRW } \\
\text { D=FT }\end{array}$ & UNIFORMITY \\
\hline m- & msukot & & & $* !$ & & & \\
\hline- -m- & səmukot & & & & & $*$ & \\
\hline$-\mathrm{u}-$ & suukot & $* !$ & $*$ & & & $*$ & \\
\hline$-\mathrm{u}-$ & sukot & & & & $* !$ & & $*$ \\
\hline
\end{tabular}

Table 5 Dependent of verbs starting with $\mathrm{Cu}$

\subsection{Vowel-initial stems}

All vowel-initial stems are prefixed with $n i$ - in the Past Tense and with $m$ - in the Dependent, regardless of the quality of their initial vowel. Examples of all possible types are given below.

$\begin{array}{llll}\text { stem } & \text { gloss } & \text { Past Tense } & \text { Dependent } \\ \text { ogkot } & \text { 'work' } & \text { nigkot } & \text { məgkot } \\ \text { abput } & \text { 'bite' } & \text { nebput } & \text { mabput } \\ \text { issa' } & \text { 'put' } & \text { nissa' } & \text { missa' } \\ \text { usur } & \text { 'tell' } & \text { nisur } & \text { musur }\end{array}$

Consider Table 6. The first, winning, candidate nesso only violates UNIFORMITY because of its vowel coalescence. The two other candidates

* onasso and *esso lack an onset and are therefore out. 


\begin{tabular}{|l|l|l|l|l|}
\hline Affix & $\begin{array}{l}\text { Stems: əgkot 'work', abput } \\
\text { 'bite', issa' 'put', usur 'tell' }\end{array}$ & ONSET & $\begin{array}{l}\text { PRWD } \\
\text { =FT }\end{array}$ & UNIFORMITY \\
\hline ni- & nigkot /nebput / nissa' / nisur & & & $*$ \\
\hline- - n- & $\begin{array}{l}\text { ənəgkot / onabput / } \\
\text { ənissa' / ənusur }\end{array}$ & $* !$ & $*$ & \\
\hline$-\mathrm{i}-$ & igkot / ebput / issa' / isur & $* !$ & $\vdots$ & $*$ \\
\hline
\end{tabular}

Table 6 Past Tense of vowel-initial verbs

The Dependent of the verb asso 'read' is shown in Table 7. The prefixed candidates mabput, magkot and missa' do not violate any constraint whereas the other candidates *omasso, *omogkot, *omissa' and *osso, *ugkot, *uissa' lack an onset.

\begin{tabular}{|l|l|l|l|l|}
\hline Affix & $\begin{array}{l}\text { Stem ogkot 'work', abput } \\
\text { 'bite', issa' 'put' }\end{array}$ & ONSET & $\begin{array}{l}\text { PRWD } \\
\text { =FT }\end{array}$ & UNIFORMITY \\
\hline $\mathrm{m}-$ & masso / məgkot / missa' & & & \\
\hline- -əm- & $\begin{array}{l}\text { əmasso / əməgkot / } \\
\text { əmissa' }\end{array}$ & $!^{*}$ & $*$ & \\
\hline$-\mathrm{u}-$ & osso/ ugkot / uissa' & $!^{*}$ & & $*$ \\
\hline
\end{tabular}

Table 7 Dependent vowel-initial verbs

Prefixation then, provides vowel-initial stems with an onset and vowel coalescence, in the case of the Past Tense, keeps them bisyllabic.

3.3 The Past Tense and Dependent affix after stems starting with a liquid Verbs starting with a liquid followed by a high vowel often display metathesis of the consonants of the first syllable when they are infixed with -on- or -om-. This metathesis is obligatory for some forms, and optional for other forms. The variation is lexically conditioned, but there may be sociolinguistic influence. Examples are given in (16).

(16)

$\begin{array}{llll}\text { stem } & \text { gloss } & \text { Past Tense } & \text { Dependent } \\ \text { liug } & \text { 'swap' } & \text { noliug } & \text { moliug } \\ \text { riu' } & \text { 'bathe' } & - & \text { moriu' } \\ \text { lauy } & \text { 'flee' } & - & \text { molauy } \\ \text { riksa' } & \text { 'examine' } & \text { noriksa'/roniksa' } & \text { moriksa'/romiksa' } \\ \text { longgo } & \text { 'lay child to sleep on } & - & \text { molonggo } \\ & \text { the floor' } & \\ \text { lera' } & \text { 'look after' } & \text { nolera'/lonera' } & \text { molera'llomera' } \\ \text { runi } & \text { 'talk' } & \text { rini } & \text { romuni }\end{array}$

Begak is not the only Austronesian language that forbids infixation of an infix that contains a sonorant after a stem-initial sonorant. ${ }^{8}$ Chamorro (Klein 2004) and Inonhan (Goudswaard 1998) also have metathesis in this context, whereas 
Toba Batak shows assimilation and Tagalog does not parse the infix in this context (Klein 2004). ${ }^{9}$

Metathesis in this context is not an OCP effect of the type "no two sonorant consonants", because it is not just any Sonorant-Vowel-Sonorant sequence that is forbidden here. The reverse order, where the infix is infixed after a non-sonorant-initial consonant but before a sonorant of the stem, C-omSonVC, does not allow metathesis, as (17) shows. If metathesis were an OCP effect, we would expect infixation without metathesis in these stems to be ungrammatical as well. ${ }^{10}$

$\begin{array}{llll}\text { stem } & \text { gloss } & \text { infixation } & \text { gloss } \\ \text { tulud } & \text { 'fly' } & \text { tomulud } & \text { 'DEP-fly' } \\ \text { tula' } & \text { 'blame' } & \text { torula' } & \text { 'REC-blame' 'blame each other' } \\ \text { tiru' } & \text { 'teach' } & \text { tomiru' } & \text { 'DEP-teach' } \\ \text { tumis } & \text { 'stirfry' } & \text { tomumis } & \text { 'DEP-stirfry' }\end{array}$

In other words, we need to invoke a constraint that refers only to the initialconsonant of the stem:

*AFF (SON): Sonorant affix avoidance

"An affix containing a sonorant is prohibited after a morpheme-initial sonorant" (Klein 2002)

This constraint interacts with the faithfulness constraint LINEARITY:

(19) LINEARITY: $S_{1}$ reflects the precedence structure of $S_{2}$ and vica versa. If $\mathrm{x}, \mathrm{y} \in \mathrm{S}_{1} ; \mathrm{x}^{\prime}, \mathrm{y}^{\prime} \in \mathrm{S}_{2} ; \mathrm{xR} \mathrm{x}^{\prime}$ and $\mathrm{xR} \mathrm{y}^{\prime}$; then $\mathrm{x}<\mathrm{y}$ iff $\mathrm{x}^{\prime}<$ $\mathrm{y}^{\prime}$.(McCarthy and Prince 1995)

The ranking of the constraints is then:

(20) ONSET, *COMPLONSET, PPN $\gg$ MORPHDIS $>$ PRWD=FT $\gg$

UNIFORMITY $\gg *$ AFF(SON), LINEARITY $\gg$

ALIGN-BY-SEG (AFFIX, WD, L)

The constraints *AFF(SON) and LINEARITY are unordered with respect to each other, in order to explain the speaker variation between metathesized and non metathesized forms.

Table 8 shows how the metathesized form can win in sonorant-initial stems. The forms prefixed with $n i$ - or $m$ - or infixed with $-i$ - or $-u$ - are ruled out for reasons described in the sections above. The form infixed with -on-or -omviolates *AFF(SON) but respects LINEARITY and is therefore optimal in some peoples speech. The metathesized form violates LINEARITY but respects *AFF(SON) and is thus the winning candidate in most people's speech. Table 8 shows the Past Tense of verbs starting with a liquid followed by /i/. The candidate prefixed with $n i$ - has a full vowel in the prepenultimate syllable and is therefore out. The last candidate infixed with $-i$ - is ruled out because it does not only have a full vowel in the prepenultimate syllable but also violates ONSET (and not shown here, the antihomophony constraint). The candidate 
infixed with - $2 n$ - and the candidate prefixed with nə- are both longer than a foot and consequently they violate $\mathrm{PRWD}=\mathrm{FT}$. The winning candidate is the one prefixed with no- as it does not violate $* \operatorname{AFF}(\mathrm{SON})$, which is ranked higher than LINEARITY.

\begin{tabular}{|c|c|c|c|c|c|c|c|}
\hline $\begin{array}{l}\text { Past } \\
\text { Tense } \\
\text { affix }\end{array}$ & $\begin{array}{l}\text { stem } \\
\text { liug } \\
\text { 'swap' }\end{array}$ & ONSET & PPN & $\begin{array}{l}\text { PRWD } \\
=\text { FT }\end{array}$ & $\begin{array}{l}{ }^{*} \mathrm{AFF} \\
(\mathrm{SON})\end{array}$ & LINEARITY & $\begin{array}{l}\text { ALIGN-BY-SEG } \\
\text { (AFFIX,WD, L) }\end{array}$ \\
\hline ni- & niliug & & $* !$ & * & & & \\
\hline -ən- & ləniug & & & * & * & & $* !$ \\
\hline -on- & noliug & & & $*$ & & $*$ & \\
\hline$-\mathrm{i}-$ & liiug & $* !$ & $*$ & & & & $*$ \\
\hline
\end{tabular}

Table 8 Past Tense of verbs starting with $\mathrm{Li}$

Table 9 shows basically the same picture as Table 8: the first and last candidates are ruled out because they violate PPN and a few other constraints. But this time the winning candidate is not the prefixed form notiru' but the infixed form toniru', as neither candidate violates *AFF(SON). The next constraint is LINEARITY, which is violated by the prefixed, metathesized form nətiru'. The winning candidate, then, is infixed form toniru'.

\begin{tabular}{|l|l|l|l|l|l|l|l|}
\hline $\begin{array}{l}\text { Past } \\
\text { Tense } \\
\text { affix }\end{array}$ & $\begin{array}{l}\text { stem } \\
\text { tiru' } \\
\text { 'teach' }\end{array}$ & ONSET & PPN & $\begin{array}{l}\text { PRWD } \\
\text { =FT }\end{array}$ & $\begin{array}{l}* \text { AFF } \\
\text { (SON) }\end{array}$ & LINEARITY & $\begin{array}{l}\text { ALIGN-BY- } \\
\text { SEG (AFFIX, } \\
\text { WD, L) }\end{array}$ \\
\hline ni- & nitiru' & & $* !$ & $*$ & & & \\
\hline -ən- & təniru' & & & $*$ & & & $*$ \\
\hline -ən- & nətiru' & & & $*$ & & $* !$ & \\
\hline -i- & tiiru' & $* !$ & $*$ & $*$ & & & $*$ \\
\hline
\end{tabular}

Table 9 Past Tense of verbs starting with $\mathrm{Ci}$

Table 10 shows how the Dependent form is derived from liquid-initial stems and is almost identical to Table 8:

\begin{tabular}{|c|c|c|c|c|c|c|c|}
\hline $\begin{array}{l}\text { Dependent } \\
\text { affix }\end{array}$ & $\begin{array}{l}\text { Stem } \\
\text { liug } \\
\text { 'swap' }\end{array}$ & $\begin{array}{l}\text { *COMPL } \\
\text { ONSET }\end{array}$ & ONSET & $\begin{array}{l}\text { PRWD } \\
=\mathrm{FT}\end{array}$ & $\begin{array}{l}\text { *AFF } \\
\text { (SON) }\end{array}$ & LINEARITY & $\begin{array}{l}\text { ALIGN-BY- } \\
\text { SEG } \\
(\text { AFFIX, } \\
\text { WD, L) }\end{array}$ \\
\hline $\mathrm{m}-$ & mliug & $* !$ & & $*$ & & & \\
\hline -əm- & ləmiug & & & $*$ & $*$ & & $* !$ \\
\hline -am- & məliug & & & * & & * & \\
\hline$-\mathrm{u}-$ & luiug & & $* !$ & & & & $*$ \\
\hline
\end{tabular}

Table 10 Dependent of verbs starting with $\mathrm{Li}$

The first candidate moliug has a complex onset and is therefore out. The last candidate lacks an onset in its second syllable and is therefore out. The 
candidate infixed with - $2 m$ - violates *AFF (SON) and is therefore ruled out. The candidate prefixed with a metathesized form of - $-2 m$ - wins.

\section{Discussion: listed allomorphs or one abstract input IN and UM?}

Until now, I have assumed that the Past Tense and Dependent affixes are listed, suppletive allomorphs that cannot be derived from an underlying abstract morpheme, for example ${ }^{*} \mathrm{IN}$ or $* \mathrm{UM}$. I will now provide some evidence for this claim. Assuming that the underlying form of the affixes is indeed $*$ IN or *UM, it is easy to derive - $2 n$ - and - $ə m$-: the vowels of $\mathrm{IN}$ and UM are reduced to schwa because of PPN. The shape of $-i$ - and $-u$ - is also predictable because of bisyllabicity as a maximum. However, the shape of $n i$ - and $m$ - is unpredictable: there is an asymmetry between the form of the Past Tense prefix $n i$ - and the Dependent prefix $m$ - We would expect them to be either both of the shape CV- $\left(n i\right.$ - and ${ }^{*} m u$ - respectively) or both of the shape C- $\left({ }^{*} n\right.$ - and $m$ respectively), but this is not the case. The shape of the allomorphs is determined by historical processes, because in Mukah Melanau (Blust 1997; Ussishkin 2000) the corresponding morphemes are nə-versus mə- versus $m u$-: the reverse of Begak. " Therefore, a listed allomorph analysis is the best way to explain the data.

\section{Conclusion}

We have seen that the Begak Past Tense and Dependent allomorphy can be best explained as suppletive allomorphy where the phonology chooses the optimal form. The choice of the optimal allomorphs is directed towards creating consonant-initial bisyllabic words, i.e. words that consist of exactly one foot. Prefixation provides vowel-initial words with an onset and infixation in combination with vowel coalescence keeps consonant-initial words bisyllabic.

Not only prosodic but also segmental constraints play a role in infixation-prefixation alternations: metathesis prevents sonorant affixes to be infixed after a sonorant.

\section{Endnotes}

ACKNOWLEDGMENT: This study was carried out as part of a research project at the Vrije Universiteit Amsterdam and is financed by the Netherlands Organization of Scientific Research (NWO) under grant number GW-350-70001. I am grateful to the Economic Planning Unit of the Prime Minister's Department of Malaysia for granting me the visa to carry out this research, and to the Sabah Muzium for sponsoring me during my stay in Sabah. I am grateful to my informants Aitim Apan, Payna Bibos, Kemisah Bibos, Patrucia Pius, Lina Tiris and Rosnani Bessing. I thank Caro Struijke for her helpful comments.

1. The Ida'an Sungai or Subpan have largely intermarried with the people living along the Segama river, who are popularly called the Dusun Segama, and no longer consitute a distinct group. 
2. The Past Tense and Dependent verb forms treated in this paper are Undergoer Voice forms by default, as they lack Actor Voice prefixes. The Actor Voice in Begak is marked with Actor Voice prefixes while the Undergoer Voice is characterized by the absence of these prefixes. The Dependent is used for imperatives, verbs of motion, successive actions in stories and after auxiliaries.

3. The optimal prosodic word is always bisyllabic in Begak, not just bimoraic. 4. There is only one exception: the Undergoer Voice Stative prefix $a$-has a full vowel. I have no explanation for this exception; perhaps this vowel receives secundary stress and is therefore footed in some way or another

5. An alternative approach is that infixes can be subcategorized for infixation and the prefixes for prefixation ( $\mathrm{Yu} 2003$ ).

6. There is evidence for anti-homophony in Begak. No transitive active (nonstative) verbal root can start with $/ \mathrm{b} /, / \mathrm{p} /, / \mathrm{m} /, / \mathrm{n} /$ or $/ \mathrm{p} /$ to avoid homophony with the prefixes $b-, p-, m-, n i-$, and $(m ə) \eta$ - respectively. Stative verbal roots can start with nasals or labials but very few stative verbal roots can be affixed with Past Tense or Dependent morphology. If a loan word starts with one of these consonants, it is deleted in the Begak adaptation: pikir 'think' from Malay becomes not *momikir (mong-pikir) in the AV but mong-ikir.

7. This constraint can be ranked anywhere as long as it is higher than PRWD=FT.

8. All examples shown in (16) start with a liquid because Begak does not have any verbal stems starting with a nasal. Another context where infixation is forbidden after a stem initial sonorant or liquid is in the Reciprocal. The Reciprocal is marked by the infix -or- if the stem starts with a consonant. Stems starting with a vowel or with a liquid mark the Reciprocal with a suppletive allomorphic process,: $\mathrm{CV}$ reduplication.

9. In the Bisayan language Inonhan the plural actor infix - $V r$-causes metathesis after an initial liquid. The examples in (i) show the ordinary infixation pattern if the stem does not start with a liquid, although it may contain one:

\begin{tabular}{|c|c|c|c|}
\hline súlat & 'read' & nag-surúlat & 'pres.perf-read-pl' \\
\hline pilá & 'spit' & nag-piríla & 'pres.perf-spit-pl' \\
\hline sáqot & 'dance' & nag-saráqot & 'pres.perf-dance-pl' \\
\hline kánta & ‘sing' & nag-karánta & 'pres.perf-sing-pl' \\
\hline$a b o ́ t$ & 'arrive' & nag-qarábot & 'pres.perf-arrive-pl' \\
\hline
\end{tabular}

The following (elicited) examples illustrate metathesis after an initial liquid:

$\begin{array}{llll}\text { (ii) líbot 'surround' } & \text { nag-rilíbot } & \text { 'pres.perf-surround-pl' } \\ \text { lohúd 'kneel' } & \text { nag-rolóhud 'pres.perf-kneel-pl' } \\ \text { lítson 'roast a pig' } & \text { nag-rilítson } & \text { 'pres.perf-roast a pig-pl' }\end{array}$

10. Another Begak infix that cannot occur after a stem-initial liquid is the Reciprocal infix -or-.:

$\begin{array}{llll}\text { (iii) } k \text { adtut } & \text { 'pinch' } & k \text {-ər-ədtut } & \text { 'pinch each other' } \\ \text { kati } & \text { 'tease' } & k \text {-ər-ati } & \text { 'tease each other' } \\ \text { tadtas } & \text { 'chase' } & t \text {-ər-adtas } & \text { 'chase each other' }\end{array}$

Reciprocals of liquid-initial stems are formed with the suppletive morphological process of prefixation with the AV-prefix gə-combined with CV-reduplication:
(iv) rakop 'wrestle' gagərakop
lapas 'pass' gəgəlapas
'wrestle with each other'
'pass each other by'




$$
\text { langu' 'relative' gogolangu' 'be relatives of each other' }
$$

There is an OCP effect to some extent: the infix -ər-cannot occur in stems that contain $/ \mathrm{r} /$.

$\begin{array}{lll}\text { (v) danggar 'bump' } & \text { gagədanggar 'bump on each other (on purpose)' } \\ \text { tiru' } & \text { 'teach' totiru' } & \text { 'teach each other' } \\ \text { taru' } & \text { 'put' totaru' } & \text { 'put on each other' }\end{array}$

The OCP effect of $/ \mathrm{r} /$ must be analysed as a distinct phenomenon that is different from the constraint against affixation after sonorants, as the OCP effect applies specifically to $/ \mathrm{r} /$ and not to any other non-initial sonorant or liquid: $t$-or-ula' 'blame each other' from $t u l a$ ' 'blame' is perfectly grammatical although the root contains a liquid $/ 1 /$.

11. In Mukah Melanau, the allomorphs $-i$ - and $-u$ - replace schwa in the stem, $n$ and $m$ - occur before vowel-initial stems, the allomorphs $m \theta^{-}$and the $m \vartheta$ before consonant-initial stems, but $m u$ - before labial-initial stems. There is no synchronic explanation for this asymmetry.

\section{References}

Alderete, John. 1995. Faithfulness to Prosodic Heads. ms., University of Massachusetts, Amherst. ROA-94-0000

Banker, John E. 1984. The Ida'an language. Languages of Sabah: a survey report, ed. by Julie K. King \& John Wayne King. Pacific Linguistics C78, Canberra: Australian National University.

Beckman, Jill. 1997. Positional Faithfulness. Ph.D. dissertation, University of Massachussetts, Amherst.

Blust, Robert. 1997. Ablaut in Northwest Borneo. Diachronica 14.1.1-30.

Goudswaard, Nelleke. 1998. Inonhan, een Bisaya taal, MA thesis. Dept. of linguistics, Vrije Universiteit Amsterdam

Klein, Thomas B. in press. Infixation and segmental constraints effects: UM and IN in Tagalog, Chamorro and Toba Batak. Lingua 2004, ROA5350802

McCarthy, John. 2002. Against gradience. ms. University of Massachusetts. Amherst: ROA \#510

McCarthy, John \& Alan Prince. 1995. Faithfulness and reduplicative identity. University of Massachusetts Occasional Papers in Linguistics 18,

Papers on Optimality Theory GLSA ed. by Jill Beckman, Laura Walsh Dickey and Suzanna Urbanczsyk, 249-384. University of Massachusetts, Amherst.

Moody, David C. 1993. Ida'an phonemics. Sabah Museum Monograph, volume 4, Kota Kinabalu.

Prince, Alan and Paul Smolensky. 1993. Optimality Theory: Constraint Interaction in Generative Grammar. ms. Rutger University and University of Colorado, Boulder, ROA\#537-0802 version 8/2002.

Steriade, Donca. 1994a. Licensing by Cue. ms., UCLA.

Steriade, Donca. 1994b. Positional Neutralization and the Expression of Contrast. ms., UCLA. 
Ussishkin, Adam. 2000. Fixed effects in Austronesian: an Optimality-Theoretic account. Proceedings of AFLA7, ed. by Marian Klamer. Vrije Universiteit Amsterdam

Alan Yu. 2003. The Morphology and Phonology of Infixation. Ph.D. dissertation. University of California, Berkeley

Zoll, Cheryl. 1998. Positional Asymmetries and Licensing. ms., MIT ROA282-0998

Nelleke Goudswaard

Vrije Universiteit Amsterdam

Letteren, Taalwetenschap

De Boelelaan 1105, 1081 HV Amsterdam 